\title{
レーザー走査方式を用いたヘッドアップディスプレイ
}

\author{
新澤 滋 \\ Microvision, Inc. ( $\bar{T} 108-6028$ 港区港南2-15-1 A-28F)
}

\section{Head Up Display with Laser Scanned Display Engine}

\author{
Shigeru SHINZAWA \\ Microvision, Inc., A-28F, 2-15-1 Konan, Minato-ku, Tokyo 108-6028
}

(Received March 23, 2010)

\begin{abstract}
There are multiple display technologies that can be used in HUD systems, including emissive displays (OLED, CRT, VFD, etc.), digital micro mirror device (DLP®), backlit LCD, micro-displays (LCOS) and scanned laser displays. Each of these technologies has its strengths and weaknesses. The majority of current HUDs use backlit LCDs. LCD technology has lent itself to effective use in HUD applications to date, but emerging technologies like scanned laser displays provide a variety of advantages over LCD in categories like brightness, color range, contrast and tolerance to windshield variations, all of which are important in human factors engineering for automotive applications.
\end{abstract}

Key Words: Head Up Display, Laser scanning, Virtual image, MEMS mirror

\section{1.はじめに}

近年，交通事故件数は年々減少してはいるが依然とし て車社会の抱える不断の課題である。そして交通事故の 主な原因の一つはドライバーのわき見運転であり，車の 運転がドライバーの能力に委ねられている限りドライ バーは常に意識を運転に集中しなければばらない。ヘッ ドアップディスプレイ(以下HUD) は文字通りドライ バーの目線を前方に保つ(ヘッドアップ)為の手段であ り，わき見をしなくても必要な情報が実視野にオーバー ラップして表示される装置である(Fig. 1). HUDは元々 戦闘機のパイロット用に開発されたものだが，その後民 間航空機や自動車に搭載されるようになった. 市販乗用 車に搭載されたのは1988年GM社の2モデルが最初であ

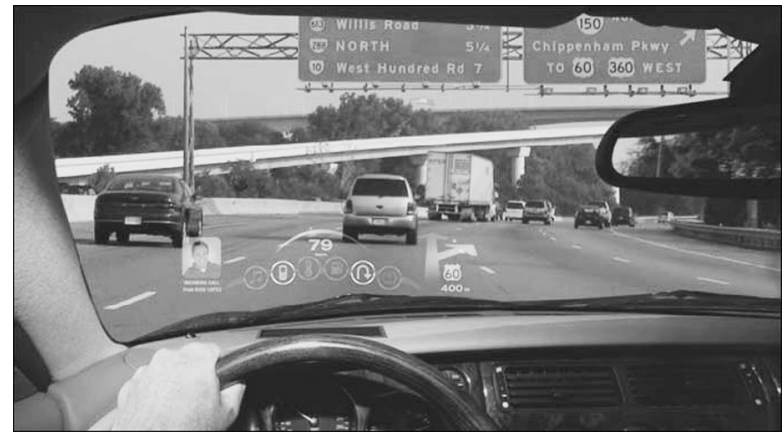

Fig. 1 Example of automotive head up display.
るが，残念ながら 10 数年を経た今日もあまり普及してい ないのが実情である。

\section{HUDの原理と技術}

HUDの原理そのものは簡単で, 蛍光管, CRT (Cathode Ray Tube)や液晶ディスプレイの画像を車のフロントガ ラスあるいはハーフミラー(コンバイナー)に映すという ものである(Fig. 2). 演説などで原稿を表示するプロン プターも原理的には同じであるが, HUDの場合には屋 外での使用が前提であり基本性能として以下が求められ る.

（1）直射日光下でも画像が認識出来ること(輝度，コ

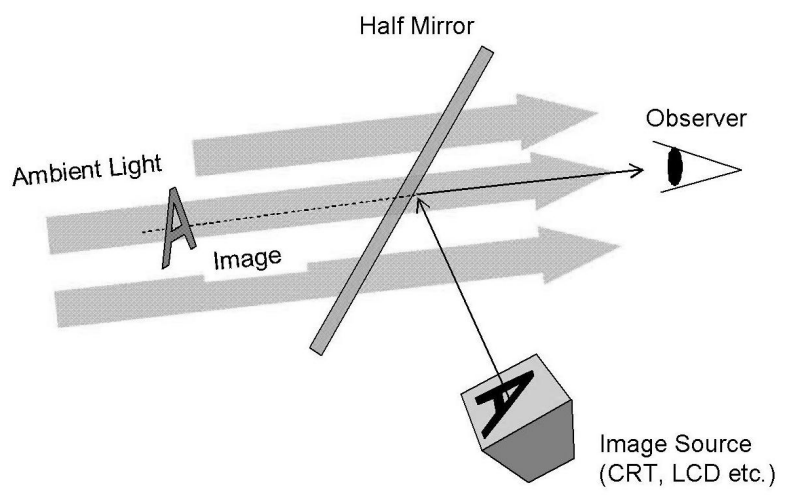

Fig. 2 Concept of head up display. 
ントラスト)

（2）車載環境(温度，振動・衝撃)にて信頼性を有する こと

（3）消費電力(発熱)が少ないこと

(4) 装置外形がコンパクトであること

HUDの光源としては，現在プロジェクターの光源とし て使用されているディスプレイが候補として挙げられ る. 方式としては, バックライト方式LCD (Liquid Crystal Display), 反射型LCOS (Liquid Crystal On Silicon), 反 射型DMD (Digital Micromirror Display)などがある。これ らにはディスプレイとしてそれぞれ特徴があるが上に挙 げたHUDとして満たすべき要件から現実的にはバック ライト方式LCDがHUDの主流となっている。そしてこ の他に, ここ数年開発が進んだ新たな方式としてレー ザー走査型ディスプレイがある.

\section{3. レーザー走査型ディスプレイ}

一昨年あたりからPico Projectorという非常に小型のプ ロジェクターが商品化され話題となっている，携帯電 話，ポータブルメディアプレイヤー，デジタルカメラな どの小さなデイスプレイ画像を数十インチに拡大して表 示できる「ユビキタスディスプレイ」として新たな市場を 形成しつつある。その一つの方式にレーザー走査型ディ スプレイがある(Fig. 3)。その動作原理は，それぞれコ リメートされた赤 $(640 \mathrm{~nm}, \mathrm{AlGaInP})$ ，青 $(450 \mathrm{~nm}$, $\mathrm{GaN})$, 緑(532 nm, 導波路型 $\mathrm{SHG}$ )のレーザー光を一本 に束ね，直交する2軸に振動するマイクロミラーに反射 させラスター走査を行う。そして，ビームが走査する間 に電気的にタイミングをとって各レーザーを同時にそれ ぞれ必要な明るさで点灯し「画素」をパルス列として形成 していく，この画素はパルス幅を変えることにより画素 単位に可変である. Fig. 4はMicrovision社のレーザー走 査型プロジェクターとそのスキャンエンジンである。解 像度はWVGA (水平848ドット×垂直480本)，フレーム レートは60 fpsでありこの時ミラーは水平方向に振れ 角 $\pm 12.6 \%$ 周波数 $18 \mathrm{KHz}$, 垂直方向に $\pm 7 \%$ Hzで振動 している

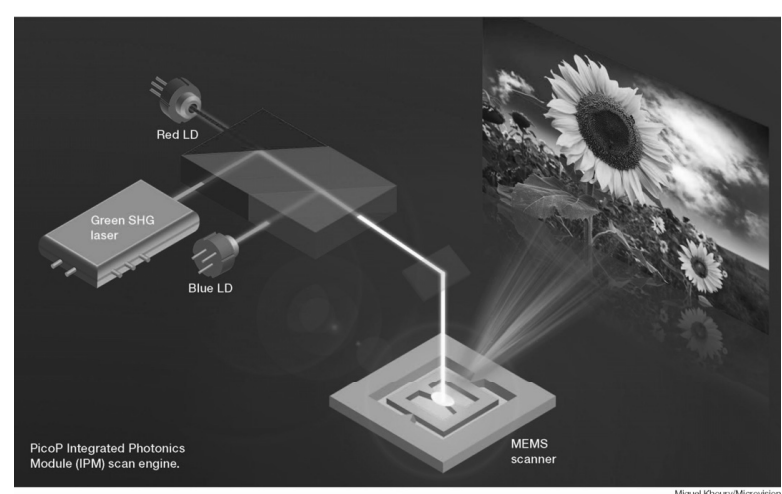

Fig. 3 Scanned laser display concept.

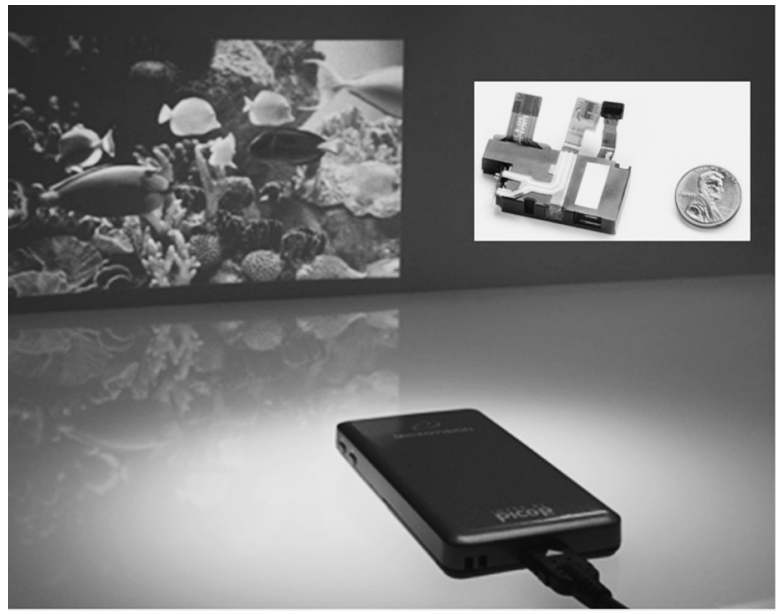

Fig. 4 Laser scanned pico projector and scan engine.

\section{4. レーザー走査型ヘッドアップディスプレイ}

プロジェクターの場合にはミラーで反射したレーザー ビームを直接スクリーンに投影してその散乱光を鑑賞す るのであるが，このスキャンエンジンを用いて非常に高 性能なHUDを実現する事が出来る．Fig. 5がその原理図 であるが，スキャンエンジンからのレーザー光の焦点面 (Image Plane)にマイクロレンズアレイで構成されたExit Pupil Expander（EPE）を置き，その後にリレー光学系を 配置することにより瞳がある範囲(Eyebox) 内にあれば 観察者にImage Planeの画像をバーチャルに認識させるこ とが可能となる，尚，この方式においてはレーザー光を 直接埕き込む事になるが，レーザー出力は玩具にも使用 が認められているクラス1であり安全性に全く問題はな い.

Fig. 6がこの方式により作製したレーザー走査方式の HUDデモンストレーターの外観である。このデモンス トレーターでは単体評価用にハーフミラー (HUDにおい ては外光とバーチャルイメージをミックスする事からコ ンバイナーとも呼ばれる)を装備しているが，実車では 車のフロントガラスをハーフミラーとして使用する場合 が多い。この場合，車のガラスはフィルムを挟んだ2重 構造をしている為そのままでは複屈折により画像にゴー ストを生じる。この為HUD用にはこれを防止した特殊 フィルムのガラスを使用する。

レーザー走査方式HUDには他方式に比較して以下の 優れた特徴がある。

(1) 高輝度・高コントラスト：

ドライバーの目の位置で測定した值で他方式では 輝度 $5,000 \mathrm{~cd} / \mathrm{cm}^{2}$ 以下であるがレーザースキャン方 式では $10,000 \mathrm{~cd} / \mathrm{cm}^{2}$ 以上を得ている. 又, レーザー スキャン方式においては黒色はレーザーの出力が極 めて小さいのでコントラスト比は他方式の数 $100: 1$ に対して5000：1と非常に高い.

(2) 外形がコンパクト：

装置全体の外形容積は約 1000 ccで従来他方式の 1/2〜1/3であり, 特に車のダッシュボードに埋め込 


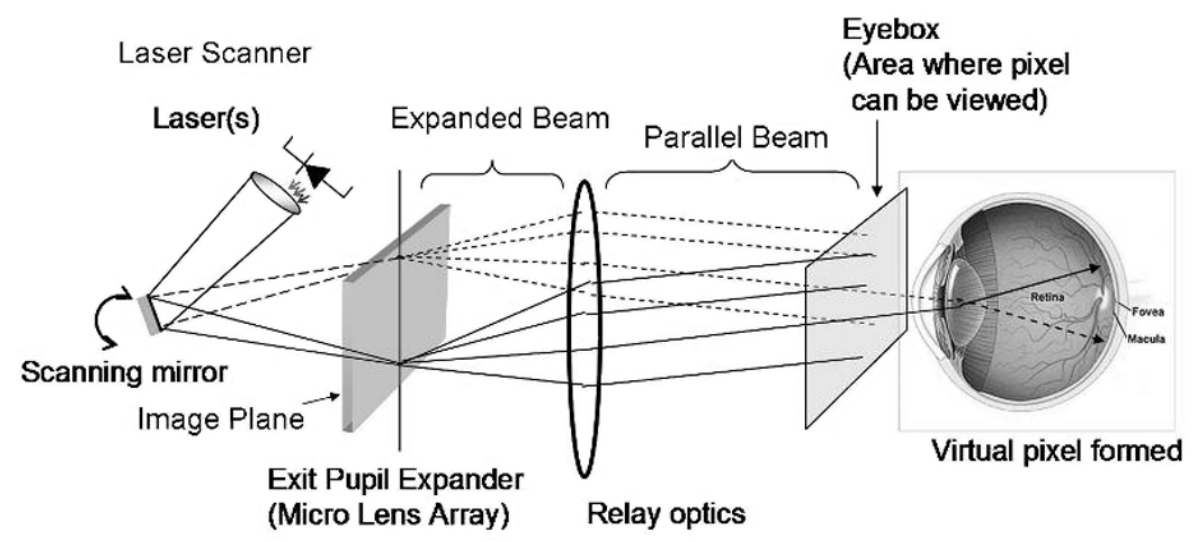

Fig. 5 Scanned laser HUD concept.

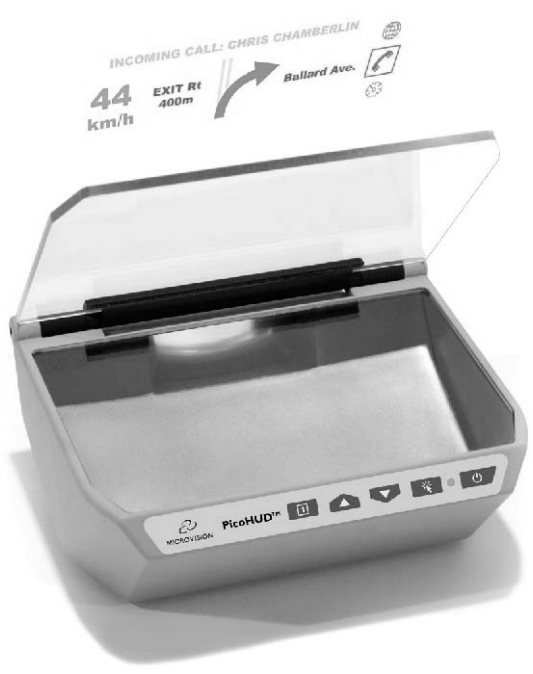

Fig. 6 Scanned laser HUD demonstrator.

むタイプでは装置の配置やダッシュボードのデザイ ンの自由度が大きい.

（3）低消費電力：

画素毎に必要な明るさでしかレーザーを発光しな いのでバックライト方式に比較して消費電力が少な い. 通常の画像表示では $10 \mathrm{~W}$ 以下, フルホワイト 表示でも20 W以下であり発熱も少なく冷却ファン などの設置も不要である。

（4）画像の歪補正が容易 :

フロントガラスをハーフミラーとして使用する場 合, ガラスの曲面形状は複雑で車種によって異なる し, 同車種でも形状のバラッキが大きい。 その為, バーチャルイメージは車ごとに異なる歪を生じ, そ の補正は製造ラインで結構手間を要する作業となっ ている、レーザースキャン方式ではこの画像歪を電 気的に比較的簡単に補正する事ができる。Fig. 7は デモンストレーターに組み込まれた画像歪補正のメ ニューである。

（5）色の再現範囲が広い：

$\mathrm{R}, \mathrm{G}, \mathrm{B}$ 各波長のレーザーを光源に使用してい る為, 色域が広く非常に鮮やかな色が表示できる。 これは実景とバーチャルイメージが重なる場合に，
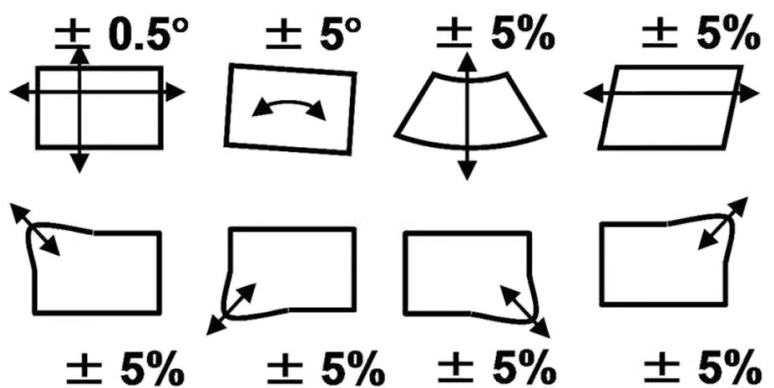

$\pm 5 \% \pm 5 \%$

$\pm 5 \%$

Fig. 7 Image Warping Menu of HUD demonstrator.

情報を背景から際立たせることになり認識が容易に なる。

（6）イメージを数メートル先に表示：

ドライバーの焦点移動が少なくて済み, 疲労軽減 と安全向上がはかれる。経験值的に画像の表示距離 は自車のボンネットの先 $2 \mathrm{~m} \sim 4 \mathrm{~m}$ 良いようであ る.

以上の様にレーザースキャン方式は車載用ヘッドアッ プディスプレイとして優れた方式であり，今後の普及が 期待されるがその為にはいくつかの課題もある.

(1) 信頼性 :

レーザースキャン方式は今までにない新しいアー キテクチャーであり，緑色レーザーやMEMSミラー など新規に開発された部品もある。現在自動車メー カーや自動車部品メーカーにて試作機の評価が進ん でいるが，厳しい信頼性条件をクリアすることが大 前提である。

(2) コスト:

新しく開発された部品やプロセスを含むのでこれ から新規の量産投資を伴うことになり，立ち上げ時 にはコスト高となることは避けられない。しかしな がら主要部品であるスキャナーはPico Projectorのエ ンジンをべースにしており，そちらが先行して量産 に移行すればスケールメリットを活かしコストダウ ンが期待できる。

（3）HUD表示シンボルのデザイン：

これはHUD自体の問題ではないが, カーライフ の多様化と高齢化が同時に進む中で，如何に的確に 
ドライバーに情報を伝えるかを考えなければならな い.その為にはまず伝える情報の種類と表現方法 (シンボル，色）をデザインし標準として統一する必 要があると思われる。

\section{5. おわりに}

HUDは交通事故を未然に防ぐ有効な手段であるが, 過去その性能とコストが普及を阻んできた。レーザー走 査方式HUDはそれらを解決しうる優れた方式である。
今後開発の進むITSなどのシステムとリンクして, 又車 に限らず陸海空の様々な交通機関のディスプレイとして 広く応用され普及する事を期待したい。

\section{参考文献}

1) H. Urey and K. D. Powell: Proc. SPIE 5456 (2004).

2) W. G. Najm, et al.: U.S. Department of Transportation National Highway Traffic Safety Administration (2006): DOT HS 810569.
射出瞳拡大素子 (exit pupil expander)

射出瞳(Exit Pupil) は光学系に拈いて像側から見た絞 りの像, あるいは接眼部を通過した光線束の太さを言 う。顕微鏡などで物体を観察する場合, 対物レンズで結 像した像は接眼レンズを介して網膜に投影されるが, 物 体から出て絞りを通過した全ての光線束が瞳孔を通過し ないと物体の全体像は見られない(ケラレ). 即ちケラレ なく物体の全体像が見える為には射出瞳は睲孔より大き くなければならない，通常瞳孔は常に動いているので射 出睲径がある程度大きくないと長時間の観察は疲労を伴
う、特にHead Up Displayの場合には車を運転しながら見 るので射出曈を拡大しないと実用にならない. Exit Pupil Expander (EPE) はこの為の光学要素である.

EPEの具体例としては回折格子, ホログラム等の拡散 板やマイクロレンズアレイなどがあり，中間結像面に配 置して光線束を拡大する。しかしこれらを光学系に挿入 することにより副作用的に各種収差が発生する為, 実用 には様々な工夫が必要である。

(新澤 滋) 